\title{
Hematological Malignancy Patients, COVID-19, and Favipiravir
} Hematolojik Malignite Hastaları, COVID-19 ve Favipiravir

(1) Rujittika Mungmunpuntipantip1, (1) Viroj Wiwanitkit2

1 Private Academic Consultant, Bangkok, Thailand

${ }^{2}$ D.Y. Patil University, Pune, India

\section{To the Editor,}

We would like to share our ideas on the "Clinical Characteristics and Outcomes of COVID-19 in Turkish Hematological Malignancy Patients." As Civriz Bozdağ et al. [1] noted in that study: "Treatments with hydroxychloroquine alone or in combination with azithromycin were associated with a higher rate of mortality in comparison to favipiravir use". First, favipiravir is an antiviral drug proposed for management of COVID-19. Compared to other alternative drugs, including hydroxychloroquine and azithromycin, favipiravir should be more specifically applied in the management of viral infections. To determine the exact usefulness of favipiravir, clinical trials and observational studies are needed for assessment of drug efficacy and safety. Comparative studies between favipiravir and other therapies would also be useful and would yield more data on favipiravir. The report cited here is a good example of this. Another example is a previous comparative study of favipiravir therapy and other antiviral drugs [2].

Regarding the effects of favipiravir, some additional considerations should be discussed. Other concurrent therapies, such as steroid medications, can also affect the clinical outcome [3]. Additional analysis of the possible effects of concurrent use of steroids with favipiravir, hydroxychloroquine, azithromycin, or their combination would be interesting. Additionally, whether the efficacy of the drug is associated with specific types and severities of hematological malignancies is a point for further research. The day of initiation of favipiravir treatment is also an important factor for therapeutic outcome [4]. According to a recent report by Doi et al. [5], early and late administrations of favipiravir result in different clinical outcomes. More data on the exact period between onset of disease and start of favipiravir are required. Regarding the present report [1], Civriz Bozdağ et al. [1] might consider additional factor analysis regarding the time effect for assessment of the effect of favipiravir. If future study designs are to be based on the current report of Civriz Bozdağ et al. [1], it may be necessary to conduct an additional prospective study from the onset of COVID-19 to the start of favipiravir administration.
Keywords: Malignancy, COVID-19, Favipiravir

Anahtar Sözcükler: Malignite, COVID-19, Favipiravir

\section{Ethics}

Informed Consent: Informed consent is not applicable for this letter to the editor.

\section{Authorship Contributions}

Concept: R.M., V.W.; Design: R.M., V.W.; Data Collection or Processing: R.M., V.W.; Analysis or Interpretation: R.M., V.W.; Literature Search: R.M., V.W.; Writing: R.M., V.W.

Conflict of Interest: No conflict of interest was declared by the authors.

Financial Disclosure: The authors declared that this study received no financial support.

\section{References}

1. Civriz Bozdağ S, Cengiz Seval G, Yönal Hindilerden I, Hindilerden F, Andıç N, Baydar M, Aydın Kaynar L, Koçak Toprak S, Göksoy HS, Balık Aydın B, Demirci U, Can F, Özkocaman V, Gündüz E, Güven ZT, Özkurt ZN, Demircioğlu $S$, Beksaç M, İnce I, Yılmaz U, Eroğlu Küçükdiler H, Abishov E, Yavuz B, Ataş Ü, Mutlu YG, Baş V, Özkalemkaş F, Üsküdar Teke H, Gürsoy V, Çelik S, Çiftçiler R, Yağcı M, Topçuoğlu P, Çeneli Ö, Abbasov H, Selim C, Ar MC, Yücel OK, Sadri S, Albayrak C, Demir AM, Güler N, Keklik M, Terzi H, Doğan A, Yegin ZA, Kurt Yüksel M, Sadri S, Yavaşoğlu I, Beköz HS, Aksu T, Maral S, Erol V, Kaynar L, IIlhan 0 , Bolaman AZ, Sevindik ÖG, Akyay A, Özcan M, Gürman G, Ünal Ş, Yavuz Y, Diz Küçükkaya R, Özsan GH. Clinical characteristics and outcomes of COVID-19 in Turkish hematological malignancy patients. Turk J Hematol 2021. doi: 10.4274/tjh.galenos.2021.2021.0287. Epub ahead of print. PMID: 34521187.

2. Çınarka $H$, Günlüoğlu $G$, Çörtük $M$, Yurt $S$, Kıyık $M$, Koşar $F$, Tanrıverdi $E$, Arslan MA, Baydili KN, Koç AS, Altın S, Cetinkaya E. The comparison of favipiravir and lopinavir/ritonavir combination in COVID-19 treatment. Turk J Med Sci 2021;51:1624-1630.

3. Murohashi K, Hagiwara E, Kitayama T, Yamaya T, Higa K, Sato Y, Otoshi R, Shintani R, Okabayashi H, Ikeda S, Niwa T, Nakazawa A, Oda T, Okuda $R$, Sekine A, Kitamura $H$, Baba T, Komatsu S, Iwasawa T, Kaneko T, Ogura T. Outcome of early-stage combination treatment with favipiravir and methylprednisolone for severe COVID-19 pneumonia: a report of 11 cases. Respir Investig 2020;58:430-434.

4. Fujii $S$, Ibe $Y$, Ishigo $T$, Inamura $H$, Kunimoto $Y$, Fujiya $Y$, Kuronuma $K$, Nakata $H$, Fukudo M, Takahashi S. Early favipiravir treatment was associated with early defervescence in non-severe COVID-19 patients. J Infect Chemother 2021;27:1051-1057. 
5. Doi $Y$, Hibino $M$, Hase $R$, Yamamoto $M$, Kasamatsu $Y$, Hirose $M$, Mutoh $Y$, Homma Y, Terada M, Ogawa T, Kashizaki F, Yokoyama T, Koba H, Kasahara H, Yokota K, Kato H, Yoshida J, Kita T, Kato Y, Kamio T, Kodama N, Uchida $Y$, Ikeda N, Shinoda $M$, Nakagawa $A$, Nakatsumi $H$, Horiguchi $T$, Iwata $M$, Matsuyama A, Banno S, Koseki T, Teramachi M, Miyata M, Tajima S, Maeki
T, Nakayama E, Taniguchi S, Lim CK, Saijo M, Imai T, Yoshida H, Kabata D, Shintani A, Yuzawa Y, Kondo M. A prospective, randomized, open-label trial of early versus late favipiravir therapy in hospitalized patients with COVID-19. Antimicrob Agents Chemother 2020;64:e01897-20.

๑Copyright 2021 by Turkish Society of Hematology

Turkish Journal of Hematology, Published by Galenos Publishing House

Received/Geliş tarihi: October 10, 2021

Accepted/Kabul tarihi: November 5, 2021

D0I: 10.4274/tjh.galenos.2021.2021.0582

\section{REPLY FROM THE AUTHORS}

In our study, we reported the clinical characteristics and outcomes of 340 adult and pediatric COVID-19 patients with hematological malignancies from March to November 2020. The aim of the study was to evaluate the factors related to severity and mortality of COVID-19 retrospectively; the study was not statistically designed to show the impact of treatment on outcomes. There was no approved treatment for COVID-19 so treatment plans in our country entailed hydroxychloroquine (HCO) alone or in combination with azithromycin as initial treatment and favipiravir for further progress of pneumonia in follow-up. In the later months, favipiravir was introduced to the initial treatment schedule for COVID-19, which resulted in the formation of different treatment groups within our retrospective data.

In multivariate analysis related to mortality, besides hematological disease status, decreased life expectancy related to primary hematological disease, neutropenia, and admission to the intensive care unit, the type of COVID-19 treatment was a significant factor. Patients treated with $\mathrm{HCO}$ alone had 4.9fold higher mortality risk in comparison to patients treated with favipiravir alone, while those treated with HCO plus favipiravir had 2.0-fold risk and those treated with $\mathrm{HCO}$ plus azithromycin had 2.1-fold risk. Favipiravir is an antiviral drug so a greater impact may be expected in comparison to $\mathrm{HCO}$. However, it should be kept in mind that the treatment policy in our country was changed after the negative results published on HCQ treatment. Furthermore, we did not have any other patients treated with different antiviral agents in our study. For patients treated with favipiravir as the initial treatment, all were treated with the drug on the day of COVID-19 diagnosis, so we do not have a second group for a comparison of the impact of the timeline, unfortunately. Anticytokine treatments were administered based on individual centers' policies so the data were heterogenous for further analyses. We agree that prospective studies would better show the outcome differences between favipiravir and other antiviral therapies.

Sinem Civriz Bozdağ, Güldane Cengiz Seval, İpek Yönal Hindilerden, Fehmi Hindilerden, Neslihan Andıç, Mustafa Baydar, Lale Aydın Kaynar, Selami Koçak Toprak, Hasan Sami Göksoy, Berrin Balık Aydın, Ufuk Demirci, Ferda Can, Vildan Özkocaman, Eren Gündüz, Zeynep Tuğba Güven, Zübeyde Nur Özkurt, Sinan Demircioğlu, Meral Beksaç, İdris İnce, Umut Yılmaz, Hilal Eroğlu Küçükdiler, Elgün Abishov, Boran Yavuz, Ünal Ataş, Yaşa Gül Mutlu, Volkan Baş, Fahir Özkalemkaş, Hava Üsküdar Teke, Vildan Gürsoy, Serhat Çelik, Rafiye Çiftçiler, Münci Yağcı, Pervin Topçuoğlu, Özcan Çeneli, Hamza Abbasov, Cem Selim, Muhlis Cem Ar, Orhan Kemal Yücel, Sevil Sadri, Canan Albayrak, Ahmet Muzaffer Demir, Nil Güler, Muzaffer Keklik, Hatice Terzi, Ali Doğan, Zeynep Arzu Yegin, Meltem Kurt Yüksel, Soğol Sadri, İrfan Yavaşoğlu, Hüseyin Saffet Beköz, Tekin Aksu, Senem Maral, Veysel Erol, Leylagül Kaynar, Osman İlhan, Ali Zahit Bolaman, Ömür Gökmen Sevindik, Arzu Akyay, Muhit Özcan, Günhan Gürman, Şule Ünal Cangül, Yasemin Yavuz, Reyhan Diz Küçükkaya, Güner Hayri Özsan 